\title{
THE TREATMENT OF SLUDGE FROM THE RUBBER PROCESSING INDUSTRY WITH CHITOSAN
}

\author{
*Ize-Iyamu, O.K ${ }^{1}$., Eguavoen, I.O²., Egbon, E.E ${ }^{1}$., Ize-Iyamu, $0 . C^{3}$., Medjor, $\mathbf{W}^{1}$. and \\ Chukwuedo, M.E ${ }^{1}$ \\ ${ }^{1}$ Department of Chemistry, Faculty of Natural Sciences, Ambrose Alli University, Ekpoma, Edo State, Nigeria. \\ ${ }^{2}$ Rubber Research Institute of Nigeria, Benin-Sapele road, Iyanomo, Edo State, Nigeria. \\ ${ }^{3}$ Department of Chemistry, Faculty of Physical Sciences, University of Benin, Benin City, Edo State, Nigeria. \\ *Corresponding author: izeiyamuosaro@gmail.com
}

\begin{abstract}
Composite sludge samples were collected from a Rubber Processing industry. The collected sludge samples were characterized according to standard procedures. The values of some of the parameters were found to be $996.55 \pm 5.85 \mathrm{NTU}, 229.00 \pm 7.80 \mathrm{mg} / \mathrm{L}$ and $1921.20 \pm 6.50 \mathrm{mg} / \mathrm{L}$ for Turbidity, BOD and COD respectively. The Total Solids (TS) and Suspended Solids (SS) were $6217.00 \pm 7.00$ and $2733.00 \pm 5.80 \mathrm{mg} / \mathrm{L}$ respectively. This portends pollution. Locally sourced coagulant, chitosan was obtained and the optimum dosage determined. It was found to be $2.10 \mathrm{~cm}^{3}$ of $1 \%$ chitosan solution per $100 \mathrm{~cm}^{3}$ sludge at pH of 7.9. On the basis of this, the sludge was treated and the treated sludge sample, characterized. Triplicate determinations were done in each case and the mean values and standard deviations obtained from statistical evaluation using the Tukey-Kramer multiple comparison tests. From the results obtained, there were significant reductions $(p-0.05)$ in pollution in measured parameters of the treated sludge samples with 74.69 $\%, 77.67 \%$ and $81.70 \%$ reduction in the COD, BOD and Turbidity respectively, thus improving the quality of the sludge in terms of toxins. The total and suspended solids increased expectedly, by $30.58 \%$ and $12.92 \%$ respectively. The coagulant was quite effective at low levels. It also showed other characteristics of locally sourced coagulants, which include less pH dependence, readily available, cheap and easy to handle, more biodegradable, therefore more environmentally friendly. The use of the coagulant for the treatment of sludge and indeed where coagulation and flocculation is desirous can be so recommended.
\end{abstract}

Keywords: Biodegradable, Chitosan, Exoskeleton, Pollution, Sludge,.

\section{INTRODUCTION}

Wastes and effluent generations are on the increase not only as a consequence of the present day challenges occasioned by our quest for technological breakthrough, industrialization, manufacturing/production of goods/services but also to attend to the ever increasing population. However, though, the consciousness of the need to protect, conserve and live in a healthy environment is encouraging. There is an increasing global concern on the environment which demands that waste should be properly managed in order to reduce their potential harm to public health and the environment. A lot still need to be done. Certain constraints are obvious and there is the need for specialized handling for effective optimization of the new trend in our present day environmental re-awakening. The wastes generated are of different constituents and present different challenges in their management. An industrial waste of which effluent is one of them is a serious issue in this regard. There have been several reports, Metcalf and Eddy (1981), Ademoroti (1996b), of the consequences of indiscriminate disposal of untreated solid wastes, effluent, e.t.c. There are known methods for the management of these wastes, however, much is not done to the wastes eventually generated at the end of most management processes/practices. One major problem emanating from such practice if well treated/managed and their resource tapped is sludge, to which little or nothing is done in its management. Several authors have defined sludge, according to Metcalf and Eddy (1981) is the settleable solids separated from liquids during processing; the deposited foreign materials on the bottoms of streams or other bodies of water. Yale (1998), defined sludge as solids, semi-solid or liquid waste derived from municipal, commercial or industrial treatment facilities, wastewater treatment plants and air pollution control. The US environmental protection agency (EPA) defined sludge as the semi - liquid residue or slurry remaining from treatment of industrial water and wastewater. Spinosa and Wichnam (2004) also defined sludge as an accumulation of solids removed from sewage during waste treatment.

The treatment of sludge renders it less of environmental nuisance and possible sources of epidemic/serious threat to public health which has been a problem both in developing and developed countries. Sludge treatment also makes it more amenable and of beneficial use to mankind taking advantage of the nutrients, soil-enhancing and fuel properties e.t.c. Sludge arising from industries have their different characteristics.

The treatment of sludge involves a lot of processes of which coagulation/flocculation belong and the use of conventional/synthetic coagulants is not entirely new, however the need to find 
sustainable alternative to these synthetic coagulants will be of immense benefits. Such alternatives that are readily available, easier and cheaper to source and handle and more environmental friendly will be desirous and the gains cannot be overemphasized. An example of such locally sourced coagulant is chitosan. Chitosan is gotten from chitin, found present in the exoskeleton in common seafoods available and consumed here in Nigeria. Chitosan has several uses, amongst which its popular use as an amazing fat absorbing dietary fibre, a natural product. It has the unique ability to attach itself to fats in the stomach before they are metabolized, trapping the fat, thereby preventing their absorption into the digestive track. Rather than being absorbed, the fat is eliminated from the body. It is called fat magnet, as it carries positive charges, lipids, fats, bile acids possess negative charges, they consequently attract one another, hence it has been recently introduced as a weight loss supplement, (Anon 2010). Chitosan is also used in plasters and bandages for treating minor cuts, wounds and injuries. It is a dietary supplement sold in USA, (Anon 2007)

\section{MATERIALS AND METHODS}

Materials: Beaker, Oven, Thermometer, Blender, Reagents: $\mathrm{NaOH},(50 \%)$, O.IM HCI

Other materials used for the analysis were the locally sourced coagulant, Chitosan, and the sludge sample from the Rubber Processing Industry.

\section{Sampling Locations}

The natural coagulant was from:

1. The Crawfish (from where Chitosan was obtained) was bought from the Royal main market, Ekpoma, Esan West local government area of Edo State, Nigeria.

2. The sludge sample was collected from a Rubber Processing industry in Benin City, Edo State, Nigeria

\section{Sampling Techniques / Preservation}

Composite sampling technique was used in the collection of the sludge from the sedimentation tank and also from the lines in the factory. The sludge was collected at two hours interval everyday for six days between the hours of $8.00 \mathrm{am}$ and $6.00 \mathrm{pm}$.

At each sampling time, one litre of the sludge was collected from the source and transferred into a 20 litre gallon kept in the refrigerator; this was done repeatedly for six days. The purpose of the refrigeration is to prevent the growth and multiplication of microorganisms and to inhibit their actions on the sludge.

Where analysis could not be carried out, samples were preserved as contained in Sample Preservatives and Holding Periods for Selected Parameters (Manual of Practice O.M.I, and Ademoroti, 1996a).

\section{Method for Extraction of Chitosan}

The procedure adopted was that of Hong and Meyers (1989). The seafood, (crawfish) was collected, sun dried for several days until it was very dried. The dried crawfish was ground with an electrical blender until it was almost fine powder. It was then transferred into a $250 \mathrm{~cm}^{3}$ beaker where it was boiled with $50 \% \mathrm{NaOH}$ at $100^{\circ} \mathrm{C}$ for 30 minutes in a solvent ratio of $1: 10$ $(w / v)$. Following deacetylation, the hot mixture was transferred to a beaker of cold water for rapid cooling. Filtration was done and the filtrate discarded while to the residue $0.1 \mathrm{M} \mathrm{HCl}$ was added to remove the mineral components before washing with distilled water till it was free of acid. Rinsing of the residue with deionized water and subsequent drying at $60^{\circ} \mathrm{C}$ for 4hours was done to get the desired chitosan needed for the sludge treatment.

\section{Physicochemical Analysis of The Raw Sludge.}

All the sludge samples from the different industries were analyzed as described in the Standard Methods for the Examination of Water and Wastewater (APHA, AWWA, WPCF. 1995) and Standard Methods for the Water and Effluent Analysis (Ademoroti 1996a). Where analysis was not immediately possible, the samples were preserved (Ademoroti, 1996a).

\section{Determination Of Optimum Dosage Of Chitosan For The Sludge Treatment.}

COD determinations were carried out severally with a constant quantity of the sludge sample $\left(100 \mathrm{~cm}^{3}\right)$ but with varying amount of chitosan for each determination and the $\mathrm{pH}$ also taken. At the end of each determination, the titre value was noted from where the COD value and \% COD reduction were calculated. The COD determination was as aforementioned, repeated severally with the same quantity of the sludge sample but varying the amount of coagulant added at each determination.

$\%$ COD reduction $=$ COD raw - COD treated $\times 100$ COD raw

$\mathrm{COD}$ raw $=\mathrm{COD}$ of the raw (untreated) sludge

COD treated $=$ COD of the repeated determinations with the different coagulant dose.

\section{Treatment Of The Samples.}

1 Litre of the sludge was collected and $21.00 \mathrm{~cm}^{3}$ of $1 \%$ chitosan solution was added simultaneously, the solution was thoroughly shaken and stirred for homogeneity with a magnetic stirrer for about $1 \mathrm{~min}$ after which it was now slowly stirred for about 15 minutes before it was allowed to stand for 1 hour in order for the coagulation and flocculation processes to effectively take place on the sludge and consequently sedimentation, having the liquor portion of the sludge separate from the settled solids.

After this treatment, the physicochemical parameters of the treated sludge were determined (using the liquor and settled solid of the sludge) as was done for the raw sludge.

\section{RESULTS AND DISCUSSION}

Table1 presents the result of the characterization of the sludge samples from the rubber processing industry. Triplicate determinations were done in each case and the mean values and standard deviations were obtained from statistical evaluation using the Tukey-Kramer multiple comparison tests.

From the table, the $\mathrm{pH}$ value of the sludge was 7.9 indicating that the sludge was weakly alkaline. The high values of $996.55 \pm 5.85 \mathrm{NTU}, 229.00 \pm 7.80$ $\mathrm{mg} / \mathrm{l}$ and $1921.20 \pm 6.50 \mathrm{mg} / \mathrm{l}$ for Turbidity, BOD and 
COD respectively show that the sludge has high pollution potentials and as a result appropriate management must be done before the sludge is put to whatever use.

The Total and Suspended Solids concentrations of $6217.00 \pm 7.00$ and $2733.00 \pm 5.80 \mathrm{mg} / \mathrm{l}$ respectively were quite high which implies that the sludge solid contents can be used for several purposes like land filling/reclamation and as a follow- up, with the relatively high values of the nutrients and low values of the heavy metals (which are within the FEPA standard/limit for industrial discharge into the environment) the sludge can be used as soil conditioner. From the Electrical Conductivity value of $185.76 \pm 6.40 \mu \mathrm{s} / \mathrm{cm}$, it indicates that the sludge sample contains ions, consequently coagulation and flocculation method can be very suitable for the treatment of this sludge.

With the Sludge Volume Index (SVI) of $62.50 \pm$ 1.32 being less than 100 , indicate that it is a well settling sludge, (Dick 1972 and Vesilind 1974). The SVI can be used for estimating the quantity of sludge that can be produced from wastewater treatment plants and indeed other potential sludge sources.

Figure 1 shows the coagulants' optimum dosage determinations for the treatment of the sludge. The optimum dosage at $\mathrm{pH}$ of 7.9 , was $2.10 \mathrm{~cm}^{3}$ of $1 \%$ chitosan solution per $100 \mathrm{~cm}^{3}$ of sludge.

Table 2 presents the results when the chitosan was used to treat the sludge sample. From the results obtained, there were significant reductions ( $\mathrm{p} \square 0.05$ ) in pollution in measured parameters indicated by the values of the parameters determined, thus, an improvement on the quality of the sludge samples with $74.69 \%, 77.67 \%$ and $81.70 \%$ reduction in the COD, BOD and Turbidity in the treated sludge sample.

There was a reduction in the heavy metal levels. The Total Solid (TS) and Suspended Solids (SS) contents increased by $30.58 \%$ and $12.92 \%$ respectively

Table 1: The Characterization Of The Untreated/Raw Sludge Samples From The Rubber Processing Industry.

\begin{tabular}{|c|c|}
\hline Parameters & Mean \pm S.D (From Triplicate Determinations) \\
\hline $\mathrm{pH}$ & $7.9 \pm 0.10$ \\
\hline Turbidity NTU & $996.55 \pm 5.85$ \\
\hline Suspended Solids (SS) mg/L & $2733.00 \pm 5.80$ \\
\hline Volatile Solids (VS) mg/L & $4822.25 \pm 4.60$ \\
\hline Total Solids (TS) mg/L & $6217.00 \pm 7.00$ \\
\hline $\mathrm{DO} \mathrm{mg} / \mathrm{L}$ & $2.75 \pm 0.04$ \\
\hline $\mathrm{BOD}_{5} \mathrm{mg} / \mathrm{L}$ & $229.00 \pm 7.80$ \\
\hline $\mathrm{COD} \mathrm{mg} / \mathrm{L}$ & $1921.20 \pm 6.50$ \\
\hline $\mathrm{HCO}_{3} \mathrm{mg} / \mathrm{L}$ & $125.75 \pm 4.60$ \\
\hline $\mathrm{Ca} \mathrm{mg/L}$ & $23.00 \pm 0.75$ \\
\hline $\mathrm{Mg} \mathrm{mg/L}$ & $22.05 \pm 0.62$ \\
\hline $\mathrm{K} \mathrm{mg/L}$ & $15.85 \pm 0.55$ \\
\hline $\mathrm{PO}_{4} \mathrm{mg} / \mathrm{g}$ & $29.27 \pm 0.81$ \\
\hline $\mathrm{NH}_{3}-\mathrm{N} \mathrm{mg/L}$ & $53.31 \pm 1.72$ \\
\hline $\mathrm{NO}_{2}-\mathrm{N} \mathrm{mg/L}$ & $32.25 \pm 1.40$ \\
\hline $\mathrm{NO}_{3}-\mathrm{N} \mathrm{mg/L}$ & $43.00 \pm 1.52$ \\
\hline $\mathrm{Fe} \mathrm{mg} / \mathrm{L}$ & $1.23 \pm 0.02$ \\
\hline $\mathrm{Zn} \mathrm{mg/L}$ & $2.87 \pm 0.05$ \\
\hline $\mathrm{Cr} \mathrm{mg} / \mathrm{L}$ & $0.68 \pm 0.02$ \\
\hline $\mathrm{Pb} \mathrm{mg} / \mathrm{L}$ & $1.01 \pm 0.04$ \\
\hline Elect. Conductivity $\mu \mathrm{s} / \mathrm{cm}$ & $185.76 \pm 6.40$ \\
\hline Temperature ${ }^{\circ} \mathrm{C}$ & $30.5 \pm 0.20$ \\
\hline Total Coliform Count TCC & $3.15 \times 10^{5} \pm 38.55$ \\
\hline Sludge Volume Index SVI ml/g & $62.50 \pm 1.32$ \\
\hline
\end{tabular}
treated sample, this undermine the use of the sludge as a source of biogas, as the reduction in VS is an indication of loss organic matter, as according to (Dick, 1972), the VS is an approximate measurement of methane gas present. The slight increase in the $\mathrm{pH}$ of the treated sludge is inconsequential, being locally sourced coagulants, as they are known to be independent on $\mathrm{pH}$. due to the conversion to nitrite and nitrate by some bacteria present in the sludge, according to (Ademoroti 1996 and Metcalf \& Eddy 1981), some groups of bacteria, Nitrosomonas and Nitrobacter do bring about such conversion.

As a consequence, this account for the increase in the nitrites and nitrates levels, invariably improving on the nutrients levels for use as soil conditioner, as nitrate is a valuable plant nutrient, (Ademoroti 1996b, Eddy and Metcalf 1981). The phosphate level also increased by $11.89 \%$ thus enhancing the fertilizer value of the sludge. There was a very significant reduction ( $\mathrm{p} \square 0.05$ ), $94.88 \%$ in the microbial load, the toxic/heavy metals contents reduced appreciably by over $40 \%$ rendering the sludge more useful for agricultural practices. The high solid contents make the sludge available to be used for land filling/reclamation and also could be used in addition with other components for block making. The sludge can contribute to the firmness and consistency in bricks as the flocs generated are large and held/bound together. Eikelboom (1997) reported the use of treated sludge with aluminium salt to have generated firmer and larger flocs.

The effectiveness of the locally sourced coagulants like jatropha gossypifolia stem latex, chitosan, had earlier been reported by (Ize-Iyamu, et al 2009) and 2011). By implication the effects was evident in the removal of the colloidal particles and consequently pollution level significantly reduced in the treated sludge. while the Volatile Solids VS reduced by $10.05 \%$ in the There was reduction in the $\mathrm{NH}_{3}-\mathrm{N}$ levels, this could be 


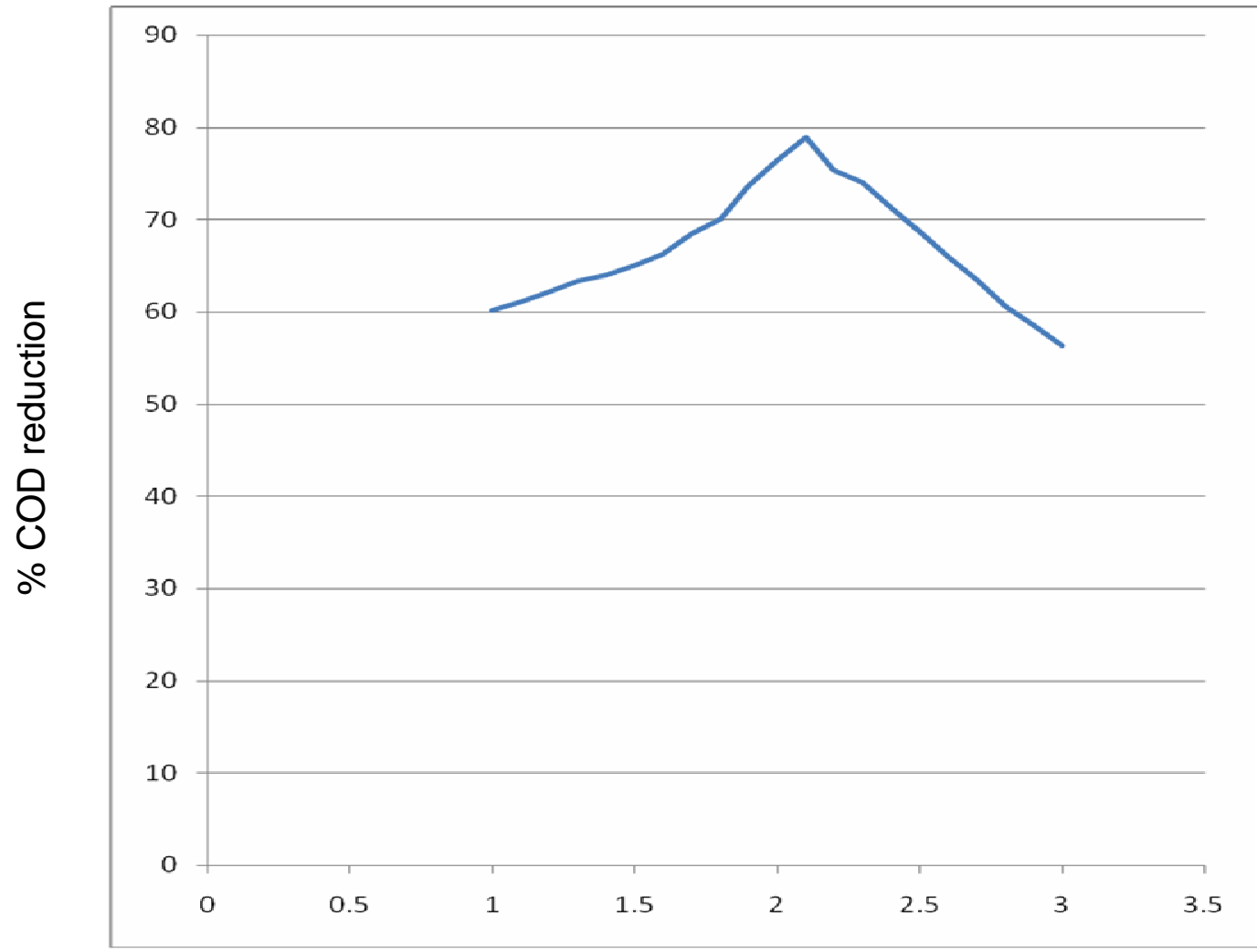

Figure 1: Optimum Dosage Determination of Chitosan for the Treatment of Rubber Processing sludge.

Table 2: Characterization Of The Treated Sludge Samples From The Rubber Processing Industry with Chitosan.

\begin{tabular}{|c|c|}
\hline Parameters & Mean \pm S.D (From Triplicate Determinations) \\
\hline $\mathrm{pH}$ & $8.0 \pm 0.2$ \\
\hline Turbidity NTU & $182.38 \pm 4.25$ \\
\hline (SS) $\mathrm{mg} / \mathrm{l}$ & $3086.13 \pm 3.60$ \\
\hline (VS) $\mathrm{mg} / \mathrm{l}$ & $4337.50 \pm 4.00$ \\
\hline (TS) $\mathrm{mg} / \mathrm{l}$ & $8118.10 \pm 5.50$ \\
\hline $\mathrm{DO} \mathrm{mg} / \mathrm{l}$ & $2.92 \pm 0.08$ \\
\hline $\mathrm{BOD}_{5} \mathrm{mg} / \mathrm{l}$ & $51.13 \pm 1.50$ \\
\hline COD mg/l & $486.27 \pm 0.10$ \\
\hline $\mathrm{HCO}_{3} \mathrm{mg} / \mathrm{l}$ & $89.00 \pm 2.05$ \\
\hline Ca mg/l & $17.69 \pm 0.50$ \\
\hline $\mathrm{Mg} \mathrm{mg/l}$ & $32.75 \pm 1.05$ \\
\hline $\mathrm{K} \mathrm{mg/l}$ & $14.45 \pm 0.50$ \\
\hline $\mathrm{PO}_{4} \mathrm{mg} / \mathrm{l}$ & $13.25 \pm 0.45$ \\
\hline $\mathrm{NH}_{3}-\mathrm{N} \mathrm{mg} / \mathrm{l}$ & $31.61 \pm 1.10$ \\
\hline $\mathrm{NO}_{2}-\mathrm{N} \mathrm{mg/l}$ & $19.91 \pm 0.72$ \\
\hline $\mathrm{NO}_{3}-\mathrm{N} \mathrm{mg/l}$ & $28.75 \pm 1.00$ \\
\hline $\mathrm{Fe} \mathrm{mg} / \mathrm{l}$ & $0.53 \pm 0 / 02$ \\
\hline $\mathrm{Zn} \mathrm{mg/l}$ & $1.36 \pm 0.05$ \\
\hline $\mathrm{Cr} \mathrm{mg} / \mathrm{l}$ & $0.32 \pm 0.01$ \\
\hline $\mathrm{Pb} \mathrm{mg} / \mathrm{l}$ & $0.42 \pm 0.02$ \\
\hline Temperature ${ }^{\circ} \mathrm{C}$ & $30.6 \pm 0.2$ \\
\hline $\mathrm{TCC} / 100 \mathrm{ml}$ & $1.61 \times 10^{4} \pm 26.50$ \\
\hline
\end{tabular}

\section{CONCLUSION AND RECOMMENDATIONS}

The disposal or reuse of sludge is a very important aspect of wastewater treatment program. Apparently treated sludge is a resource that can be beneficially used in more than one way, such use options might include agricultural or industrial reuse by the discharging community as direct is change to support the aquatic environment of the receiving water. 
Processing and disposal of sludge that is economic and environmental friendly is currently of great importance to local authority and industry. The use of locally sourced coagulant proved effective and as good as the synthetic ones. Consequently they could be used alongside synthetic coagulants and in the very near future be possible replacement for the synthetic ones and thus recommended for use not

\section{REFERENCES}

Ademoroti, C.M.A (1996a): Standard Methods for water and Effluent Analysis. Ibadan: Foludex Press Ltd.

Ademoroti, C.M.A (1996b): Environmental Chemistry and Toxicology. Ibadan: Foludex Press Ltd.

American Public Health Association, APHA (1995): Standard Methods for the Examination of Water and Wastewater. $16^{\text {th }}$ ed. Washington, D.C.

Anon. http://www.coagulant/flocculants.ask.com. April $23^{\text {rd }} 2007$

Anon. www.vanderbilt.edu Jan 21th, 2010.

Dick, R.I. (1972): "Sludge Treatment" in Physicochemical Processes For Water Quality Control. New York: John Wiley \& Sons Inc.

Eikelboom, D.H. (1997): Is Licht Slib in moderrne, communale installaties nogeen problem. studiedag Licht Slib: Technologisch Institut, Genootschap Milieutechnologie. Antwerpen.

FEPA (1988): National Guidelines and Standards For Industrial Effluents, Gaseous Emissions and Hazardous Wastes Management in Nigeria. Federal Ministry of Works and Housing. 33101

Hong, K. No and Meyers, P.S (1989): Crawfish Chitosan as a Coagulant in Recovery of Organic Compounds from Seafood Processing Streams. Journal of Agricultural Food Chemistry, American Chemical Society. 37: $580-583$. only in sludge treatment, but also in water and wastewater treatment and indeed whenever coagulation and flocculation is desired. Locally sourced coagulants are safe to use, they are non-corrosive and easy to handle. Their other advantages include; their effectiveness in very low dosage, they don't pose problems in terms of residual metal contamination and are cheap and readily available locally.

Ize-Iyamu, O.K., Eguavoen, I.O., Asia, I.O., Egbon, E.E., Ize-Iyamu, O.C, Ebesunun, B, (2009): Comparative Studies on The Treatment of Brewery Sludge Using Locally Sourced and Conventional Coagulants. Journal of Adv. Nat. \& Appl. Sci. Res. 7: 200-208.

Ize-Iyamu, O.K., Eguavoen, I.O., Osuide, M.O., Egbon, E.E., Ize-Iyamu, O.C, Akpoveta, V., Ibizubge, O.O. (2011): Characterization and Treatment of Sludge from the Brewery Using Chitosan. The Pacific journal of Science and Technology, 12 (1): 542-547.

Manual of Practice No O.M.I(1980): Wastewater Sampling for Process and Quality Control. Water Pollution Control Fed. Alexandria, Va

Eddy and Metcalf (1981): Wastewater Engineering: Treatment, Disposal, Reuse. $2^{\text {nd }}$ ed. New York: McGraw Hill..

Spinosa, L and Wichmann, K. (2004): Sludge Characterization: The Role of Physical Consistency. Journal of Water Science and Technology. 49: (10) 59-65

U.S. Environmental Protection Agency (1985): A Manual Design for Dewatering Municipal Wastewater Sludge.

Vesilind, A.P. (1974): Treatment and Disposal of Wastewater Sludges, Michigan: Ann Arbor Science Publishers Inc, 11-23.

Yale, J.D (1998): Sludge Management Concise Encyclopedia of Science and Technology. 251-273.

\section{Appendix}

Table for Figure 1

\begin{tabular}{lcl} 
COD raw $=1921.20 \mathrm{mg} / \mathrm{L}$. & Sludge $\mathrm{pH}=6.9$ & \\
\hline Coagulant Dose $\left(\mathbf{c m}^{\mathbf{3}}\right)$ & $\mathbf{C O D}(\mathbf{m g} / \mathbf{L})$ & \% COD Reduction \\
\hline 1.00 & 765.21 & 60.17 \\
1.80 & 574.25 & 70.11 \\
1.90 & 505.47 & 73.69 \\
2.00 & 452.25 & 76.46 \\
$\mathbf{2 . 1 0}$ & 404.99 & $\mathbf{7 8 . 9 2}$ \\
2.20 & 472.42 & 75.41 \\
2.30 & 498.94 & 74.03 \\
2.40 & 552.92 & 71.22 \\
2.50 & 603.06 & 68.61 \\
3.00 & 839.76 & 56.29 \\
\hline
\end{tabular}

